\title{
PENGEMBANGAN MEDIA PEMBELAJARAN DENGAN APLIKASI MACROMEDIA FLASH PADA MATA PELAJARAN MATEMATIKA
}

\author{
Try Yayuk Junita Wulandari ${ }^{1}$, Sahat Siagian ${ }^{2}$, Abdul Muin Sibuea ${ }^{3}$ \\ ${ }^{1}$ SMP Swasta Dwitunggal, Tanjung Morawa, Sumatera Utara \\ ${ }^{2,3}$ FT Universitas Negeri Medan, Sumatera Utara \\ tryjunitawulandari@gmail.com
}

\begin{abstract}
Abstrak: Penelitian ini bertujuan untuk: menghasilkan produk media pembelajaran berbasis multimedia interaktif yang layak digunakan, mudah dipelajari pebelajar dan dapat dipakai untuk pembelajaran individual. Jenis penelitian pengembangan model pengembangan produk Borg dan Gall model desain pembelajaran Dick dan Carey. Hasil penelitian menunjukkan: (1) uji ahli materi kualifikasi sangat baik (88,88\%), (2) uji ahli desain pembelajaran kualifikasi sangat baik (87,77\%), (3) uji ahli media pembelajaran kualifikasi sangat baik (84,44\%), (4) uji coba perorangan kualifikasi sangat baik (84,12\%), (5) uji coba kelompok kecil kualifikasi sangat baik (89,97\%), dan (6) uji coba lapangan terbatas kualifikasi sangat baik (92,02\%), dan layak untuk digunakan dalam proses pembelajaran Matematika. Hasil pengujian hipotesis membuktikan bahwa terdapat perbedaan yang signifikan antara hasil belajar siswa yang dibelajarkan dengan menggunakan buku ajar dengan hasil belajar siswa yang dibelajarkan dengan menggunakan buku teks. Hal ini ditunjukkan dengan hasil pengolahan data diperoleh thitung $=6,557>$ ttabel $=2,024$, dengan $d k=(n 1+n 2-2)$ pada taraf signifikansi $\alpha=0,05$. Disimpulkan bahwa hasil belajar kelompok siswa yang dibelajarkan dengan menggunakan buku ajar sebesar 78,38\% lebih tinggi dari kelompok siswa yang dibelajarkan dengan menggunakan buku teks sebesar 65,71\%.
\end{abstract}

Kata Kunci: media pembelajaran, macromedia flash, matematika

\begin{abstract}
This study aims to: produce interactive multimedia-based learning media products that are feasible to use, easily learned by students and can be used for individual learning. This type of research is developing the Borg and Gall product development model of Dick and Carey's learning design model. The results of the study showed: (1) the expert test was very good qualification (88.88\%), (2) the learning design expert test was very good qualifications $(87.77 \%)$, (3) the test media learning expert qualifications were very good (84 44\%), (4) individual qualification trials are very good (84.12\%), (5) small group trials of very good qualifications (89.97\%), and (6) field trials are limited to very good qualifications $(92,02 \%)$, and is suitable for use in the process of learning Mathematics. The results of hypothesis testing prove that there are significant differences between student learning outcomes learned by using textbooks with student learning outcomes learned by using textbooks. This is indicated by the results of data processing obtained by tcount $=$ $6.557>t$ table $=2.024$, with $d k=(n 1+n 2-2)$ at the significance level $\alpha=0.05$. It was concluded that the group learning outcomes of students who were taught using textbooks were $78.38 \%$ higher than the group of students who were taught using textbooks of $65.71 \%$.
\end{abstract}

Keywords: learning media, flash macromedia, mathematics

\section{PENDAHULUAN}

Matematika adalah Ilmu yang paling banyak manfaatnya di dalam kehidupan ini. Di dalam kehidupan sehari-hari mulai dari hal yang paling sederhana sampai hal yang paling kompleks semuanya menggunakan ilmu matematika. Matematika walaupun tidak semua orang menyukainya tanpa disadari selalu digunakan setiap waktu. Matematika dikenal sebagai ilmu dasar. Pembelajaran matematika akan melatih kemampuan berpikir kritis, logis, analitis, dan sistematis. Tetapi peran matematika tidak hanya sebatas hal tersebut. Perkembangan bidang ilmu lain, seperti fisika, biologi, ekonomi ataupun berbagai bidang ilmu sosial, tidak terlepas dari peran matematika. 
Matematika juga sangat pantas disebut sebagai jembatan ilmu pengetahuan dan teknologi. Sebagai contoh, kemajuan teknologi luar angkasa yang sangat pesat di jaman sekarang karena kemajuan bidang ilmu fisika. Tetapi kemajuan ilmu fisika itu sendiri tidak akan tercapai tanpa peran matematika dan perkembangan matematika itu sendiri.

Kehadiran media sangat dibutuhkan dalam pembelajaran sebagaimana yang dikemukakan oleh para peneliti sebelumnya. Kritianto (2010:8), era perkembangan teknologi informasi yang semakin meningkat, khususnya dalam teknologi komputer sangat berpengaruh dan berperan penting dalam dunia pendidikan. Terutama dalam media pembelajaran, yaitu sering disebut denga komputer pembelajaran atau Computer Assited Instruktional (CAI). Penggunaan media tersebut sangat membantu sekali dalam proses belajar siswa secara mandiri. Aplikasi program yang disajikan meliputi teks, grafis, animasi, video, dan sound. Aplikasi program tersebut dapat menarik perhatian dalam proses belajar mengajar.

Sementara menurut Driscoll (2002:21) ada empat prinsip yang dapat digunakan dalam menentukan kerangka kerja guru untuk berfikir tentang bagaimana teknologi dapat mendukung pengajaran: (1) pembelajaran terjadi pada konteks, termasuk cara teknologi dapat memfasilitasi pembelajaran dengan menyediakan konteks dunia nyata yang melibatkan peserta didik dalam memecahkan masalah yang kompleks, dan simulasi computer dan computer berbasis dunia mikro yang menawarkan konteks untuk peserta didik dalam mengeksplorasi dan memahami fenomena yang kompleks dalam berbagai subyek daerah, (2) belajar aktif, termasuk penggunaan brainstorming, pemetaan konsep, atau visualisasi perangkat lunak, serta simulasi yang memungkinkan peserta didik untuk bereksperimen dengan pemodelan ide-ide yang kompleks. (3) belajar adalah sosial, termasuk software yang mendukung lingkungan, jaringan multimedia dimana siswa berkolaborasi pada kegiatan pembelajaran dan di luar kelas, sehingga lebih mudah untuk melakukan umpan balik, refleksi, dan revisi.

Berdasarkan hasil studi pendahuluan dengan menganalisis kebutuhan guru dan siswa yang diperoleh penulis di SMP Swasta Dwitunggal Tg.Morawa yang dilaksanakan melalui wawancara guru dan siswa. Hasil wawancara dengan guru bidang studi Matematika Juliana (2014), diperoleh informasi bahwa media di SMP Swasta Dwitunggal Tg,Morawa sangat terbatas jadi agak sulit menyampaikan materi yang memerlukan visualisasi, siswa hanya mengandalkan pembelajaran bersumber dari guru. Semua itu disebabkan tidak adanya atauu masih minimnya penggunaan media pembelajaran dalam proses pembelajaran di kelas yang mengakibatkan Nilai rata-rata pada pelajaran Matematika masih tergolong rendah, karena masih ada siswa yang belum mencapai ketuntasan minimal yaitu 70 .

\section{Hakikat Hasil Belajar Matematika.}

Dimyati dan Mudjiono (2009:3) :

Belajar merupakan suatu proses internal yang kompleks, yang terlibat dalam proses internal tersebut adalah yang meliputi unsur afektif, dalam matra afektif berkaitan dengan sikap, nilai-nilai, interes, apresiasi, dan penyesuaian perasaan sosial. Belajar menurut kamus besar bahasa indonesia adalah berusaha memperoleh kepandaian atau ilmu, berlatih, berubah tingkah laku atau tanggapan yang disebabkan oleh pengalaman. Banyak definisi para ahli tentang belajar, di antaranya adalah sebagai berikut:

(1) Hilgard (dalam Sanjaya, 2008): learning is the process by which an activity originates or changed through training procedures (wether in the laboratory or in the natural environment) as distinguished from changes by factors not attributable to training (belajar adalah proses perubahan melalui kegiatan atau prosedur latihan baik latihan di dalam laboratorium maupun dalam lingkungan alamiah).

(2) Hudoyo (1990:8): belajar merupakan kegiatan bagi setiap orang. Seseorang dikatakan belajar, bila dapat diasumsikan dalam diri orang itu menjadi suatu proses kegiatan yang mengakibatkan suatu perubahan tingkah laku. Reber (dikutip Suprijono, 2010): belajar adalah proses mendapatkan pengetahuan.

(3) Riyanto (2010:12): seseorang dikatakan belajar kalau dapat melakukan sesuatu dengan cara latihan-latihan sehingga yang bersangkutan menjadi berubah. Sagala (2010:3): belajar merupakan suatu proses perubahan prilaku atau pribadi seseorang berdasarkan praktek dan pengalaman tertentu. 
(4) Sardiman (2008:7): belajar merupakan perubahan tingkah laku atau penampilan dengan serangkaian kegiatan, misalnya membaca, menulis dan sebagainya serta belajar itu akan lebih baik jika si subjek mengalami dan melakukannya.

(5) Slameto (2010:4): belajar pada hakikatnya adalah suatu proses usaha yang dilakukan seseorang untuk memperoleh perubahan tingkah laku yang baru secara keseluruhan, sebagai hasil pengalamannya sendiri dalam interaksinya dengan lingkungan.

Sudjana (2010:2), dalam belajar merupakan suatu proses yang ditandai dengan adanya perubahan pada diri seseorang. Perubahan hasil proses belajar dapat ditunjukkan dalam berbagai bentuk seperti penambahan pengetahuan, pemahaman, sikap dan tingkah laku, kecakapan, kebiasaan serta perubahan aspek-aspek lain yang ada pada individu-individu yang belajar. Hasil belajar merupakan tujuan akhir dilaksanakannya kegiatan pembelajaran di sekolah. Hasil belajar dapat ditingkatkan melalui usaha sadar yang dilakukan secara sistematis mengarah kepada perubahan yang positif yang kemudian disebut dengan proses belajar. Akhir dari proses belajar adalah perolehan suatu hasil belajar siswa. Hasil belajar siswa di kelas terkumpul dalam himpunan hasil belajar kelas. Semua hasil belajar tersebut merupakan hasil dari suatu interaksi tindak belajar dan tindak mengajar. Dari sisi guru, tindak mengajar di akhiri dengan proses evaluasi hasil belajar, sedangkan dari sisi siswa, hasil belajar merupakan berakhirnya penggal dan puncak proses belajar (Dimyati dan Mudjiono, 2009:3).

Menurut Sudjana (2010:22), hasil belajar adalah kemampuan yang dimiliki siswa setelah menerima pengalaman belajar. Selanjutnya Warsito (dalam Depdiknas, 2006:125) mengemukakan bahwa hasil dari kegiatan belajar ditandai dengan adanya perubahan perilaku ke arah positif yang relatif permanen pada diri orang yang belajar. Sehubungan dengan pendapat itu, maka Wahidmurni, dkk. (2010:18) menjelaskan bahwa sesorang dapat dikatakan telah berhasil dalam belajar jika ia mampu menunjukkan adanya perubahan dalam dirinya. Perubahanperubahan tersebut di antaranya dari segi kemampuan berpikirnya, keterampilannya, atau sikapnya terhadap suatu objek.
Jika dikaji lebih mendalam, maka hasil belajar dapat tertuang dalam taksonomi Bloom, yakni dikelompokkan dalam tiga ranah (domain) yaitu domain kognitif atau kemampuan berpikir, domain afektif atau sikap, dan domain psikomotor atau keterampilan. Sehubungan dengan itu, Gagne (dalam Sudjana, 2010:22) mengembangkan kemampuan hasil belajar menjadi lima macam antara lain: (1) hasil belajar intelektual merupakan hasil belajar terpenting dari sistem lingsikolastik; (2) strategi kognitif yaitu mengatur cara belajar dan berfikir seseorang dalam arti seluas-luasnya termaksuk kemampuan memecahkan masalah; (3) sikap dan nilai, berhubungan dengan arah intensitas emosional dimiliki seseorang sebagaimana disimpulkan dari kecenderungan bertingkah laku terhadap orang dan kejadian; (4) informasi verbal, pengetahuan dalam arti informasi dan fakta; dan (5) keterampilan motorik yaitu kecakapan yang berfungsi untuk lingkungan hidup serta memprestasikan konsep dan lambang.

Untuk mengetahui hasil belajar seseorang dapat dilakukan dengan melakukan tes dan pengukuran. Tes dan pengukuran memerlukan alat sebagai pengumpul data yang disebut dengan instrumen penilaian hasil belajar. Menurut Wahidmurni, dkk. (2010:28), instrumen dibagi menjadi dua bagian besar, yakni tes dan non tes. Selanjutnya, menurut Hamalik (2006:155), memberikan gambaran bahwa hasil belajar yang diperoleh dapat diukur melalui kemajuan yang diperoleh siswa setelah belajar dengan sungguh-sungguh. Hasil belajar tampak terjadinya perubahan tingkah laku pada diri siswa yang dapat diamati dan diukur melalui perubahan sikap dan keterampilan. Perubahan tersebut dapat diartikan terjadinya peningkatan dan pengembangan yang lebih baik dibandingkan dengan sebelumnya.

Prestasi belajar siswa juga dapat dikaitkan dengan tingkat kecerdasan peserta didik. Upaya untuk mengetahui tingkat kecerdasan telah dilakukan oleh para ahli psikologi, antara lain pada tahun 1905 Alfred Binet mengembangkan test intelegensi yang digunakan secara luas. Binet berhasil menemukan cara untuk menentukan usia mental seseorang. Usia mental mungkin lebih rendah, lebih tinggi atau sama dengan usia kronologis (usia yang dihitung secara kelahirannya). Anak yang cerdas akan memiliki usia mental lebih tinggi daripada usianya sendiri, karena mampu 
mengerjakan tugas-tugas untuk anak yang usianya lebih tinggi (Mulyasa, 2004:121).

Istilah Matematika berasal dari bahasa

Yunani, mathein dan mathenem yang berarti mempelajari. Kata matematika diduga erat hubungannya dengan kata sansekerta, medha atau widya yang artinya kepandaian, ketahuan atau intelegensi. (Nasution, 1980: 2). Kata matematika berasal dari perkataan latin matematika yang mulanya diambil dari perkataan yunani mathematike yang berarti mempelajari. Perkataan itu mempunyai asal katanya mathemayang berarti pengetahuan dan ilmu (knowledge, science).

Kata matematika berhubungan pula dengan kata lainnya yang hampir sama, yaitu mathein atau mathenein yang artinya belajar (berpikir). Pendefinisian matematika sampai saat ini belum ada kesepakatan yang bulat, namun demikian dapat dikenal melalui karakteristiknya. Russeffendi, (1980 :148) berdasarkan asal katanya, maka perkataan matematika berarti ilmu pengetahuan yang didapat dengan berpikir (bernalar). Matematika lebih menekankan kegiatan dalam dunia rasio (penalaran), bukan menekankan dari hasil eksperimen atau hasil observasi matematika terbentuk karena pikiran-pikiran manusia, yang berhubungan dengan idea, proses, dan penalaran Mustafa (dalam Wijayanti, 2011) menyebutkan bahwa matematika adalah ilmu tentang kuantitas, bentuk, susunan, dan ukuran, yang utama adalah metode dan proses untuk menemukan dengan konsep yang tepat dan lambang yang konsisten, sifat dan hubungan antara jumlah dan ukuran, baik secara abstrak, matematika murni atau dalam keterkaitan manfaat pada matematika terapan.

Tinggih (2003:16), matematika berarti ilmu pengetahuan yang diperoleh dengan bernalar. Hal ini dimaksudkan bukan berarti ilmu lain diperoleh tidak melalui penalaran, akan tetapi dalam matematika lebih menekankan aktivitas dalam dunia rasio (penalaran), sedangkan dalam ilmu lain lebih menekankan hasil observasi atau eksperiment disamping penalaran.

Pembelajaran matematika yang diajarkan pada setiap jenjang pendidikan baik Sekolah Dasar (SD), Sekolah Menengah Pertama (SMP), dan Sekolah Menengah Atas (SMA) tidak sepenuhnya sama dengan matematika sebagai ilmu. Menurut Soedjadi (2000:37) hal ini dikarenakan adanya perbedaan dalam beberapa hal yaitu: 1) penyajiannya yang disesuaikan dengan perkembangan intelektual perseta didik; 2) menggunakan pola pikir deduktif namun dalam proses pembelajaran dapat digunakan pola pikir induktif; 3) keterbatasan semestanya yang lebih dipersempit dari aspek matematika yang kompleks dan selanjutnya semakin diperluas seiring dengan peningkatan perkembangan perseta didik; 4) tingkat keabstrakannya yang lebih dikurangi dan selanjutnya sifat abstraknya semakin banyak seiring dengan peningkatan perkembangan perseta didik.

\section{Hakikat Media Pembelajaran}

Kegiatan pembelajaran merupakan interaksi antara siswa dan guru. Mengajar dapat diartikan sebagai suatu kegiatan atau aktivitas dalam rangka menciptakan suatu situasi dan kondisi belajar siswa yang kondusif. Menurut Sanjaya (2011:101) “ Mengajar dalam konteks standard pendidikan tidak hanya sekedar penyampaian materi pelajaran, akan tetapi dimaknai sebagai proses mengatur lingkungan, penyediaan alat dan sumber pembelajaran dan hal-hal lain yang memungkinkan siswa betah dan merasa senang belajar, sehingga mereka dapat berkembang secara optimal sesuai dengan bakat, minat dan potensi yang dimiliki”.

Hal ini sesuai dengan pendapat Briggs (1979: 212-213) yang menyatakan bahwa media pembelajaran sebagai "the physical means of conveying instructional content..book, films, videotapes, etc". Lebih jauh Briggs menyatakan media adalah "Alat untuk memberi perangsang bagi siswa supaya terjadi proses belajar. Sedangkan mengenai efektifitas media. Brown (1970) menggaris bawahi bahwa media yang digunakan guru atau siswa dengan baik dapat mempengaruhi efektifitas proses belajar dan mengajar.

Beberapa pemahaman itu antara lain : (1) media merupakan wadah dari pesan yang oleh sumber pesan ataupun penyalurnya ingin diteruskan kepada sasaran atau penerima pesan tersebut. (2) aplikasi media pembelajaran berpijak pada kaidah ilmu komunikasi, yang antara lain dikatakan Lasswell (1982: 90) "who says what in which channels to whom in what effect". Secara rinci dapat diuraikan sebagai berikut : (1) Who, siapa yang menyatakan? (guru, widyaiswara, instruktur, fasilitatordan semua yang berfungsi sebagai pengirim pesan). (2) What, pesan atau ide/gagasan apa yang disampaikan (dalam kegiatan pembelajaran ini 
berarti bahan ajar atau materi yang akan disampaikan). (3) Which Channels, dengan saluran apa, media saluran apa, media atau sarana apa, pesan itu ingin disampaikan. (4) To Whom, kepada siapa (sasaran, siswa, peserta didik). (5) What effect, dengan hasil atau dampak apa?. Dari unsur-unsur di atas, tampaknya yang menjadi target (goal) dari suatu kegiatan pembelajaran adalah dampak atau hasil yang ingin dicapai dalam kegiatan pembelajaran.

Dalam suatu proses belajar mengajar, dua unsur yang sangat penting adalah metode mengajar dan media pengajaran. Kedua aspek ini saling berkaitan. Pemilihan salah satu metode mengajar tertentu akan mempengaruhi jenis media pengajaran yang sesuai, meskipun masih ada berbagai aspek lain yang harus diperhatikan dalam memilih media, antara lain tujuan pengajaran, jenis tugas dan respon yang diharapkan siswa kuasai setelah pengajaran berlangsung, dan konteks pembelajaran termasuk karakteristik siswa. Meskipun demikian, dapat dikatakan bahwa salah satu fungsi utama media pengajaran adalah sebagai alat bantu mengajar yang turut mempengaruhi iklim, kondisi, dan lingkungan belajar yang ditata dan diciptakan oleh guru. Hamalik (2009:171) mengemukakan bahwa pemakaian media pengajaran dalam proses belajar mengajar dapat membangkitkan keinginan dan minat yang baru, membangkitkan motivasi dan rangsangan kegiatan belajar, dan bahkan membawa pengaruh-pengaruh psikologis terhadap siswa.

Media pembelajaran yang beraneka ragam jenisnya tentunya tidak akan digunakan seluruhnya secara serentak dalam kegiatan pembelajaran, namun hanya beberapa saja. Untuk itu perlu di lakukan pemilihan media tersebut. Agar pemilihan media pembelajaran tersebut tepat, maka perlu dipertimbangkan faktor/kriteria-kriteria dan langkah-langkah pemilihan media. Kriteria yang perlu dipertimbangkan guru atau tenaga pendidik dalam memilih media pembelajaran menurut Sudjana (2010:10) adalah sebagai berikut: (1) Ketepatannya dengan tujuan pengajaran. Artinya media pengajaran dipilih atas daasr tujuan-tujuan instruksional yang ditetapkan. Tujuan-tujuan instruksional yang berisikan unsur pemahaman apliksi, analisis, sentesis lelah memungkinkan digunakannya media pengajaran. (2) Dukungan terhadap isi bahan pengajaran; artinya bahan pengajaran yang bersifat fakta, prinsip, konsep dan generalisasi sangat memerlukan bantuan media agar lebih mudah dipahami siswa. (3) Kemudahan memperoleh media; artinya media diperlukan mudah diperoleh, setidak-tidaknya mudah dibuat oleh guru pada waktu mengajar. Media grafis umunya dapat dibuat guru tanpa biaya yang mahal, disamping sederhana dan praktis penggunaannya. (4) Keterampilan guru dalam menggunakannya; apa pun jenis media yang diperlukan syarat utama adalah guru dapat menggunakannya dalam proses pengajaran. Nilai dan manfaat yang diharapkan bukan pada medianya, tetapi dampak dari penggunaan oleh guru pada saat terjadinya interaksi belajar siswa dan lingkungannya. Adanya OHP, proyektor film, komputer dan alat-alat canggih lainnya, tidak mempunyai arti apa-apa bila guru tidak dapat menggunakannya dalam pengajaranuntuk mempertingggi kualitas pengajaran. (5) Tersedia waktu untuk menggunakannya; sehingga media tersebut dapat bermanfaat bagi siswa selama pengajaran berlangsung.

Selain itu, menurut Dick dan Carey (2003:83) menyebutkan bahwa di samping kesesuaian dengan tujuan perilaku belajarnya, setidaknya masih ada empat faktor lagi yang perlu dipertimbangkan dalam pemilihan media, yaitu: (1) Ketersediaan sumber tempat. Artinya bila media yang bersangkutan tidak terdapat pada sumber-sumber yang ada, maka harus dibeli atau dibuat sendiri. (2) Apakah untuk membeli atau memproduksi sendiri tersebut ada dana, tenaga dan fasilitasnya. (3) Faktor yang menyangkut keluwesan, kepraktisan dan ketahanan media yang bersangkutan untuk waktu yang lama. Artimya bisa digunakan dimanapun dengan peralatan yang ada disekitarnya dan kapan pun serta mudah dijinjing dan dipindahkan. (4) Efektivitas biayanya dalam jangka waktu yang panjang. Pelaksanaan proses belajar mengajar, terdapat dua hal yang teramat penting adalah metode mengajar yang digunakan serta dukungan dari media yang digunakan. Kedua aspek tersebut saling terkait satu sama lain. Pemilihan metode pembelajaran sangat mempengaruhi media pembelajaran yang digunakan. Hal tersebut berarti bahwa pemilihan media pembelajaran harus didasarkan pada metode pembelajaran yang digunakan.

Ada empat fungsi media pembelajaran, khususnya media visual menurut Sudjana 
(2001:45), yaitu : (1). Fungsi atensi, Media visual merupakan inti, yaitu menarik dan mengarahkan perhatian siswa untuk berkonsentrasi kepada isi pelajaran yang berkaitan dengan makna visual yang ditampilkan atau menyertai teks materi pelajaran. (2). Fungsi afektif Media visual dapat terlihat dari tingkat kenikmatan siswa ketika belajar (atau membaca) teks yang bergambar. (3). Fungsi kognitif Media visual terlihat dari temuan- temuan penelitian yang mengungkapkan bahwa lambing visual atau gambar memperlancar pencapaian tujuan untuk memahami dan mengingat informasi atau pesan yang terkandung dalam gambar.

Berbagai manfaat media pembelajaran telah dibahas oleh banyak ahli. Menurut Kemp \& Dayton ( 1985;3-4 ) meskipun telah lama didasari bahwa banyak keuntungan penggunaan media pembelajaran, penerimanya serta pengintregasiannya kedalam program-program pengajaran berjalan amat lambat. Mereka mengemukakan beberapa hasil penelitian yang menunjukan dampak positif dari penggunaan media sebagai bagian integral pembelajaran di kelas atau sebagai cara utama pembelajaran langsung sebagai berikut : (1) Penyampaian pelajaran menjadi lebih baku. Setiap pelajaran yang melihat atau mendengar penyajian melalui media menerima pesan yang sama. Meskipun para guru menafsirkan isi pelajaran dengan cara yang berbeda-beda, dengan penggunaan media ragam hasil tafsiran itu dapat dikurangi sehingga informasi yang sama dapat disampaikan kepada siswa sebagai landasan atau pengkajian, latihan dan implikasi lebih lanjut, (2) Pembelajaran bisa lebih menarik. Media dapat diasosiasikan sebagai penarik perhatian dan membuat siswa tetap terjaga dan memperhatikan. Kejelasan dan keruntutan pesan, daya tarik image yang berubah-ubah, penggunaan efek khusus yang dapat menimbulkan keingintahuan menyebabkan siswa tertawa dan berfikir, yang kesemuanya menunjukan bahwa media memiliki aspek motifasi dan meningkatkan minat, (3) Pembelajaran menjadi lebih interaktif dengan diterapkan teori belajar dan prinsip-prinsip psikologis yang diterima dalam hal partisipasi siswa, umpan balik, dan penguatan. (4) Lama waktu pembelajaran yang diperlukan dapatdipersingkat karena kebanyakan media hanya memerlukan waktu singkat untuk mengantarkan pesan-pesan dan isi pelajaran dalam jumlah yang cukup banyak dan kemungkinannya dapat diserap oleh siswa, (5) Kualitas hasil belajar dapat ditingkatkan bila mana integrasi kata dan gambar sebagai media pembelajaran dapat mengkomunikasikan elemen-elemen pengetahuan dengan cara yang terogranisasikan dengan baik, spesifik dan jelas. (6) Pembelajaran dapat diberikan kapan dan dimana diinginkan dan diperlukan terutama jika media pembelajaran dirancang untuk penggunaan secara individu, (7) Sikap positif siswa terhadap apa yang mereka pelajari dan terhadap proses belajar dapat ditingkatkan. (8) Peran guru dapat berubah kearah yang lebih positif beban guru untuk penjelasan yang berulang-ulang mengenai isi pelajaran yang dapat dikurangi bahkan dihilngkan sehingga ia dapat memusatkan perhatian kepada aspek penting lain dalam proses belajar mengajar, misalnya sebagai konsultan atau penasihat siswa.

Dale (1969:180) mengemukakan bahwa bahan-bahan audio-visual dapat memberikan banyak manfaat asalkan guru berperan aktif dalam proses pembelajaran. Hubungan gurusiswa tetap merupakan elemen paling penting dalam sistem pendidikan modern saat ini. Guru harus selalu hadir untuk menyajikan materi pembelajaran dengan bantuan media apa saja agar bermanfaat, berikut ini dapat terealisasi: (1) Meningkatkan rasa saling pengertian dan simpati dalam kelas; (2) Membuahkan perubahan signifikan tingkah laku siswa; (3) Menunjukan hubungan antara mata pelajaran dan kebutuhan dan minat siswa dengan meningkatkan motovasi beljar siswa, (4) Membawa kesegaran dan variasi bagi pengalaman belajar siswa, (5) Membuat hasil belajar lebih bermakna bagi berbagai kemampuan siswa, (6) Mendorong pemanfaatan yang bermakna dari mata pelajaran dengan jalan melibatkan imajinasi dan partisipasi aktif yang mengakibatkan hasil belajar, (7) Memberikan umpan balik yang diperlukan yang dapat membantu siswa menemukan seberapa banyak telah mereka pelajari, (8) Melengkapi pengalaman yang kaya dengan pengalaman itu konsep-konsep yang bermakna dapat dikembangkan, (9) Memperluas wawasan dan pengalaman siswa yang mencerminkan pembelajaran nonverbalistik dan membuat generalisasi yang tepat, (10) Menyakinkan diri bahwa urutan dan kejelasan pikiran yang siswa 
butuhkan jika mereka membangun struktur konsep dan sistem gagasan yang bermakna.

Purwanto (2006: 84) mengemukakan empat fungsi media pembelajaran khususnya media visual adalah: (1) fungsi atensi yaitu menarik dan mengarahkan perhatian siswa untuk berkonsentrasi kepada isi pembelajaran yang berkaitan dengan makna visual yang ditampilkan, (2) fungsi afektif yang dapat mengubah emosi dan sikap siswa, (3) fungsi kognitif yang memperlancar pencapaian tujuan untuk memahami dan mengingat informasi atau pesan yang terkandung dalam gambar, dan (4) kompensatoris yaitu memberikan konteks untuk memahami teks dan memabantu siswa yang lemah dalam membaca dan mengorganisasikan informasi.

Media pembelajaran memiliki peran yang berbeda-beda sesuai dengan kegunaan pembelajaran. Peran dari media akan terasa jika diletakkan pada posisi yang tepat. Penggunaan media pembelajaran sebagai alat bantu tidak boleh sembarangan dibuat karena harus mempertimbangkan kesesuaian antara kegunaan dan tujuan pembelajaran. Menurut Wena (2009: 204), konsep dari peran media pembelajaran sebagai berikut: (1) objek yang ditransformasikan melalui media akan berusaha secara cermat melukiskan konsep suatu pembelajaran yang abstrak; (2) penggunaan media pembelajaran akan membuat kegiatan pembelajaran berlangsung tepat guna dan berdaya guna sehingga hasil belajar siswa dapat ditingkatkan. Menurut Sudjana dan Rivai yang ditulis oleh Wena (2009: 2), peranan media pembelajaran dalam proses belajar siswa adalah sebagai berikut:

1. menumbuhkan motivasi belajar siswa karena pembelajaran akan lebih menarik perhatian siswa;

2. bahan pembelajaran menjadi jelas maknanya karena siswa lebih mudah memahami pembelajaran sehingga memungkinkannya untuk menguasai dan mencapai tujuan pembelajaran;

3. metode mengajar menjadi lebih bervariasi sehingga siswa tidak bosan; dan

4. siswa lebih banyak melakukan kegiatan pembelajaran sebab siswa tidak hanya mendengarkan uraian guru, namun siswa juga mendemonstrasikan dan memerankan kegiatan pembelajaran.

Prawiradilaga

(2012:106)

mengemukakan rumusan media pembelajaran matematika dihasilkan para ahli dari berbagai sudut pandang. Dalam wawasan sistem, Bretz menyatakan tiga fungsi media pembelajaran adalah sebagai sistem, subsistem, dan pengayaan. Media pembelajaran yang dikembangkan sebagai suatu sistem, memiliki komponen lengkap layaknya suatu sistem pembelajaran. Biasanya media ini disiapkan untuk belajar mandiri. Media sebagai subsistem adalah media pembelajaran yang digunakan sebagai bagian dari penyajian pengajar. Penggunaannya sangat bergantung atas kompetensi pengajar. Media untuk pengayaan adalah media yang disiapkan sebagai suatu pilihan bagi peserta didik agar ia mampu menguasai lebih dari yang dirumuskan dalam tujuan pembelajaran. Untuk wacana penyampaian, Prawiradilaga (2012: 106) menuliskan pemanfaatan media pembelajaran menekankan besarnya jumlah peserta didik yang dijangkau. Ada media pembelajaran yang dikembangkan untuk satu orang peserta didik, seperti Computer-Assisted Instruction (CAI) lalu ada media pembelajaran yang cocok digunakan untuk beberapa orang peserta didik yang terbentuk sebagai kelompok belajar seperti flipchart, namun ada juga media pembelajaran yang dapat menjangkau sejumlah besar peserta didik seperti pemanfaatan TV pendidikan. Secara umum manfaat media pembelajaran adalah memperlancar interaksi antara guru dan siswa sehingga kegiatan pembelajaran akan lebih efektif dan efisien. Tetapi secara khusus ada beberapa manfaat media yang lebih rinci yang dikemukakan oleh beberapa ahli.

Media pembelajaran matematika. Media pembelajaran matematika adalah segala sesuatu yang dapat menyalurkan pengetahuan dari pendidik (sumber informasi) kepada siswa (penerima informasi ) dalam pembelajaran matematika. yang paling banyak digunakan dalam pembelajran matematika yaitu media cetak, media elektronik, media model dan petakonsep Menurut H.W. Fowler (Suyitno, 2000: 1) matematika adalah ilmu yang mempelajari tentang bilangan dan ruang yang bersifat abstrak. Sehingga untuk menunjang kelancaran pembelajaran di samping pemilihan metode yang tepat juga perlu digunakan suatu media pembelajaran yang sangat berperan dalam membimbing abstraksi siswa (Suyitno, 2000: 37). Adapun nilai atau fungsi khusus media pendidikan matematika antara lain: (1) 
untuk mengurangi atau menghindari terjadinya salah komunikasi; (2) untuk membangkitkan minat atau motivasi belajar siswa; (3) untuk membuat konsep matematika yang abstrak, dapat disajikan dalam bentuk konkret sehingga lebih dapat dipahami, dimengerti, dan dapat disajikan sesuai dengan tingkat-tingkat berpikir siswa. (Darhim, 1993: 10)

Komputer merupakan jenis media yang secara virtual dapat menyediakan respon yang segera terhadap hasil belajar yang dilakukan oleh siswa. Lebih dari itu, komputer memiliki kemampuan menyimpan dan memanipulasi informasi sesuai dengan kebutuhan. Perkembangan teknologi yang pesat saat ini telah memungkinkan komputer memuat dan menayangkan beragam bentuk media di dalamnya. Dalam hal ini Heinich, Molenda, \& Russel (1996: 228) mengemukakan bahwa : "...It has ability to control and integrate a wide variety of media - still pictures, graphics and moving images, as well as printed information. The computer can also record, analyze, and react to student responses that are typed on a keyboard or selected with a mouse".

Jayadi (2008:6) macromedia flash adalah salah satu program software yang mampu menyajikan pesan audiovisual secara jelas kepada siswa dan materi yang bersifat nyata, sehingga dapat diilustrasikan secara lebih menarik kepada siswa dengan berbagai gambar animasi yang dapat merangsang minat belajar siswa untuk mencapai tujuan pembelajaran. Sedangkan menurut Madcom (2004:12) Macromedia Flash 8.0 adalah program grafis yang diperuntukan untuk motion atau gerak dan dilengkapi dengan script untuk programming (action script) dengan program ini memungkinkan pembuatan animasi media interaktif, game.

Wirawan Istiono dalam Andriyanto (2010) menjelaskan bahwa Macriomedia Flash 8.0 adalah suatu program aplikasi berbasis vektor standar authoring tool professional yang digunakan untuk membuat animasi dan bitmap yang sangat menarik untuk membuat animasi logo, movie, game, menu interaktis, dan pembuatan aplikasi-aplikasi web. Selanjutnya menurut Prasetio dalam Cahyono (2010) "Macromedia Flash adalah suatu suatu software animasi yang dapat digunakan untuk mempermudah penyampaian suatu konsep yang bersifat abstrak yang dalam penerapannya menggunakan komputer dan media imager proyector."

Menurut Andriyanto (2012: 4-5) bahwa Software Macromedia Flash 8.0 sangat berguna dalam mendukung kesuksesan sebuah presentasi dan proses belajar mengajar (PBM). Dalam Macromedia Flash 8.0, kita dapat memasukan elemen-elemen seperti gambar atau movie, animasi, presentasi, game. dapat digunakan sebagai tool untuk mendesain web, dan berbagai aplikasi multimedia lainnya.(1) Kelebihan macromedia flash diantaranya adalah Seorang pemula yang masih awam terhadap dunia desain dan animasi dapat mempelajari dan memahami Macromedia Flash dengan mudah tanpa harus dibekali dasar pengetahuan yang tinggi tentang bidang tersebut. (2) Pengguna program Macromedia Flash dapat dengan mudah dan bebas dalam berkreasi membuat animasi dengan gerakan luwes (bebas) sesuai dengan alur adegan animasi yang dikehendakinya. (3) Macromedia Flash ini dapat menghasilkan file dengan ukuran kecil. Hal ini dikarenakan Flash menggunakan animasi dengan basis vektor. (4) Macromedia Flash menghasilkan file bertipe (ekstensi). Flash yang bersifat fleksibel, karena dapat dikonversikan menjadi file bertipe .swf, .html, .gif, .jpg, .png, .exe, .mov.

Rumusan masalah dalam penelitian ini adalah: (1) Apakah penggunaan media pembelajaran audiovisual (menggunakan macromedia flash) pada mata pelajaran matematika layak digunakan?; (2) Apakah penggunaan media pembelajaran audiovisual (menggunakan macromedia flash) pada mata pelajaran matematika efektif digunakan?

\section{METODE}

Penelitian ini dilaksanakan di SMP Swasta Dwitunggal yang berlokasi di jalan medan - tg.morawa km.14,5 Tg.Morawa pada siswa kelas VII semester genap. Seluruh siswa kelas VII SMP Swasta Dwitunggal Tg.Morawa yang berjumlah 2 kelas yaitu: kelas VII-1, VII2 , dengan jumlah 40 siswa. Dari seluruh populasi diambil seluruh kelas VII sebagai kelas uji coba lapangan. Tahap pelaksanaan penelitian ini dilaksanakan pada semester genap dengan sampel yang terdiri dari satu kelas berjumlah 40 orang peserta didik.

Model Borg and Gall merupakan salah satu model penelitian dan pengembangan pendidikan yang sangat populer. Jika seseorang 
ingin mengembangkan atau membuat sebuah produk pendidikan dapat dilakukan dengan menggunakan model ini. Prosedur penelitian pengembangan menurut Borg and Gall (1979: 626).

1. Melakukan penelitian pendahuluan dan pengumpulan data awal untuk kaji pustaka, pengamatan kelas, identifikasi permasalahan dan merangkum permasalahan.

2. Melakukan perencanaan yaitu identifikasi dan definisi keterampilan, perumusan tujuan, dan uji ahli atau uji coba pada skala kecil, atau expert judgement.

3. Mengembangkan jenis/ bentuk produk awal meliputi: penyiapan materi pembelajaran, penyusunan buku petunjuk, dan perangkat evaluasi.

4. Melakukan uji coba tahap awal, dilakukan terhadap 1-3 sekolah menggunakan 6-12 subjek. Pengumpulan informasi/ data dengan menggunakan observasi, wawancara, dan kuesioner, dan dilanjutkan analisis data.

5. Melakukan revisi terhadap produk utama, berdasarkan input dan saran-saran dari hasil uji lapangan awal.

6. Melakukan uji coba lapangan utama

7. Melakukan revisi terhadap produk operasional, berdasarkan input dan saransaran hasil uji lapangan utama.

8. Melakukan uji lapangan operasional, data dikumpulkan melalui wawancara, observasi, dan kuesioner.

9. Melakukan perbaikan terhadap produk akhir, berdasarkan saran dalam uji coba lapangan

10.Mendesiminasikan dan mengimplementasikan produk, melaporkan dan menyebarluaskan produk melalui pertemuan dan jurnal ilmiah, bekerjasama dengan penerbit untuk sosialisasi produk untuk komersial, dan memantau distribusi dan kontrol kualitas.

Analisis data dalam penelitian menggunakan analisis deskriptif kuantitatif. Semua data yang terkumpul dianalisis denga teknik statistik deskriptif yang secara kuantitatif dipisahkan menurut kategori untuk mempertajam penilaian dalam menarik kesimpulan. Data kualitatif yang berupa pernyataan sangat kurang baik, kurang baik, sedang, baik, dan sangat baik diubah menjadi data kuantitatif dengan skala nilai 1 sampai 5. Hasilnya dirata - ratakan dan digunakan untuk menilai kualitas video pembelajaran. kriteria akan dikonversikan menjadi nilai dengan skala menggunakan Likert yang dianalisis secara deskriptif persentase dengan rumus sebagai berikut (Sugiyono, 2007):

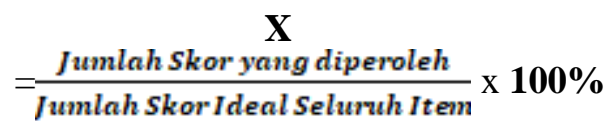

Tabel 1.Kriteria Persentase Kemunculan Indikator pada Media Pembelajaran Interaktif Materi Segitiga dan Segiempat yang telah dikembangkan.

\begin{tabular}{clc}
\hline Nilai & \multicolumn{1}{c}{ Kriteria } & Persentase \\
\hline A & Sangat Baik & $80 \% \leq \mathrm{X} \leq 100 \%$ \\
B & Baik & $60 \% \leq \mathrm{X} \leq 100 \%$ \\
C & Sedang & $40 \% \leq \mathrm{X} \leq 60 \%$ \\
D & Kurang Baik & $20 \% \leq \mathrm{X} \leq 40 \%$ \\
\hline E & Sangat Kurang Baik & $0 \% \leq \mathrm{X} \leq 20 \%$ \\
\hline
\end{tabular}

Keterangan $\mathrm{X}=$ skor empiris

Apabila hasil yang diperoleh sudah mencapai kriteria minimal $61 \%$ maka media pembelajaran ini dinyatakan sudah dapat dimanfaatkan dengan layak untuk proses pembelajaran Matematika.

Penelitian ini dilakukan di SMP Swasta Dwitunggal Morawa. Populasi dalam penelitian ini adalah siswa kelas VII SMP Swasta Dwitunggal yang berjumlah 2 kelas, yaitu kelas VII-1 dan Kelas VII-2. Teknik pengambilan sampel dalam penelitian ini adalah Non Probality Sampling yaitu jenis Sampling Purvosive Sampel, sehingga sampel dalam penelitian ini adalah seluruh siswa kelas V II SMP Swasta Dwitunggal.

Penelitian ini melibatkan dua kelas, yaitu kelas eksperimen dan kelas kontrol dimana kedua kelas ini diberi tes sebanyak dua kali yaitu pre test dan post test. Adapun langkah-langkah yang ditempuh dalam melaksanakan penelitian ini adalah :

a. Tahap awal yaitu : mengkonfirmasi ke sekolah tentang kegiatan penelitian ini, membuat jadwal penelitian, menyusun rencana pembelajaran, pretes, perlakuan dan post tes.

b. Tahap pelaksanaan.

Penelitian dilaksanakan pada semester genap dengan sampel yang terdiri dari dua kelas yakni kelas eksperimen yang diajarkan dengan menggunakan buku ajar dan kelas kontrol yang diajarkan dengan menggunakan buku teks. Untuk mendapatkan hasil akhir diberikan tes pada kedua kelas dengan instrument yang sama yaitu tes objektif sebanyak 30 soal. 
Instrumen yang digunakan yaitu tes hasil belajar aspek pengetahuan yang berbentuk pilihan berganda yang berjumlah 30 soal yang masing-masing terdiri dari option jawaban $a, b$, c dan d. Teknik pemberian skor untuk soal objektif ini berdasarkan benar atau salah, artinya siswa yang menjawab benar pada setiap butir soal akan diberi skor 3,33 (tiga koma tiga tiga) dan bagi siswa yang menjawab salah akan diberikan skor 0 (nol) sehingga skor minimal 0 dan skor maksimal 100.

Untuk melihat apakah ada perbedaan yang signifikan antara hasil belajar dengan penggunaan buku ajar dan buku teks dilakukan dengan menggunakan uji beda (uji-t) (Sudjana,1989) yaitu :

$$
\mathrm{t}=\frac{\overline{\mathrm{X}_{1}}-\overline{\mathrm{X}_{2}}}{\mathrm{~s} \sqrt{\frac{1}{\mathrm{n}_{1}}+\frac{1}{\mathrm{n}_{2}}}}
$$

dimana $S$ adalah varians gabungan yang dihitung dengan rumus :

$$
\mathrm{S}^{2}=\frac{\left(\mathrm{n}_{1}-1\right) \mathrm{S}_{1}^{2}+\left(\mathrm{n}_{2}-1\right) \mathrm{S}_{2}^{2}}{\mathrm{n}_{1}+\mathrm{n}_{2}-2}
$$

Dengan $\mathrm{dk}=\left(\mathrm{n}_{1}+\mathrm{n}_{2}-2\right)$, kriteria korelasi yang diperoleh dikatakan signifikan (hipotesis diterima) jika harga $t_{\text {hitung }}>t_{\text {tabel }}$ untuk taraf signifikasi 0,05. Untuk melihat keefektifas buku ajar yang dieksperimenkan digunakan rumus perhitungan efektifitas berikut (Sugiyono, 2011).

$\mathrm{X}=\frac{\text { jumlah skor yang diperoleh }}{\text { jumlah skor ideal seluruh item }} \mathrm{x} 100 \%$

Pasangan hipotesis nol dan hipotesis alternatif yang akan diuji adalah : Hipotesis $\left(\mathrm{H}_{\mathrm{a}}\right.$ dan $\mathrm{H}_{\mathrm{o}}$ ) dalam uraian kalimat :

$\mathrm{H}_{\mathrm{o}}$ : Rata-rata hasil belajar siswa yang menggunakan media pembelajaran macromedia flash 8.0 dalam belajarnya lebih tinggi dari pada siswa yang menggunakan buku teks.

$\mathrm{H}_{\mathrm{a}}$ : Rata-rata hasil belajar antara siswa yang menggunakan media pembelajaran macromedia flash 8.0 dalam belajarnya lebih rendah dari pada siswa yang menggunakan buku teks

Model statistiknya adalah :

$\mathrm{H}_{\mathrm{o}} \quad: \mu_{1}>\mu_{2}$

$\mathrm{H}_{\mathrm{a}}: \mu_{1} \leq \mu_{2}$

dengan

$\mu_{1}$ : Rata-rata hasil belajar siswa yang menggunakan buku ajar berbasis kontekstual

$\mu_{2}$ : Rata-rata hasil belajar siswa yang menggunakan buku teks

\section{HASIL PENELITIAN}

Tabel 2. Skor Penilaian Media Pembelajaran Mata Pelajaran Matematika Pada Uji Coba

\begin{tabular}{|c|c|c|c|c|c|c|c|}
\hline \multirow{2}{*}{ No } & \multirow{2}{*}{ Indikator Penilain } & \multicolumn{3}{|c|}{ Responden } & \multirow[t]{2}{*}{ JlhSkor } & \multirow{2}{*}{$\begin{array}{l}\text { Penyamp } \\
\text { aian }\end{array}$} & \multirow[t]{2}{*}{ Kriteria } \\
\hline & & 1 & 2 & 3 & & & \\
\hline 1 & $\begin{array}{l}\text { Teks atau tulisan dalam media mudah } \\
\text { dibaca }\end{array}$ & 4 & 4 & 5 & 13 & $86,67 \%$ & B \\
\hline 2 & Gambar yang disajikan jelas atau tidak & 4 & 4 & 4 & 12 & $80 \%$ & B \\
\hline 3 & $\begin{array}{l}\text { Gambar yang disajikansudah sesuai } \\
\text { (tidak terlalu banyak dan sedikit) }\end{array}$ & 4 & 3 & 4 & 11 & $73 \%$ & B \\
\hline 4 & $\begin{array}{l}\text { Adanya keterangan pada setiap gambar } \\
\text { yang disajikan di video }\end{array}$ & 4 & 5 & 5 & 14 & $93,33 \%$ & SB \\
\hline 5 & Gambar yang disajikan menarik & 4 & 4 & 4 & 12 & $80 \% \%$ & B \\
\hline \multirow[t]{2}{*}{6} & $\begin{array}{l}\text { Gambar yang disajikan sesuai dengan } \\
\text { materi }\end{array}$ & 4 & 4 & 5 & 13 & $86,67 \%$ & $\mathrm{~B}$ \\
\hline & Rata-rata & & & & 8,33 & $83,27 \%$ & SB \\
\hline
\end{tabular}
Perorangan Tentang Kualitas Materi Pelajaran.Tentang Aspek Tampilan.

Keterangan: $\mathrm{SB}=$ Sangat baik ; B = Baik 
Tabel 3. Skor Penilaian Media Pembelajaran Mata Pelajaran Matematika Pada Uji Coba Perorangan Tentang Kualitas Materi Pelajaran.Tentang Aspek Penyajian Materi.

\begin{tabular}{|c|c|c|c|c|c|c|c|}
\hline \multirow{2}{*}{ No } & \multirow{2}{*}{ Indikator Penilain } & \multicolumn{3}{|c|}{ Responden } & \multirow{2}{*}{$\begin{array}{l}\text { Jumla } \\
\text { h Skor }\end{array}$} & \multirow{2}{*}{$\begin{array}{l}\text { Penyam } \\
\text { paian }\end{array}$} & \multirow{2}{*}{$\begin{array}{l}\text { Krite } \\
\text { ria }\end{array}$} \\
\hline & & 1 & 2 & 3 & & & \\
\hline 1 & $\begin{array}{l}\text { Media ini menjelaskan konsep dengan } \\
\text { menggunakan ilustrasi masalah yang berkaitan } \\
\text { dengan kehidupan sehari-hari }\end{array}$ & 4 & 3 & 4 & 11 & $73 \%$ & $\mathrm{~B}$ \\
\hline 2 & $\begin{array}{l}\text { Media menggunakan contoh-contoh yang berkaitan } \\
\text { dengan masalah kehidupan sehari-hari }\end{array}$ & 4 & 4 & 4 & 12 & $80 \%$ & $\mathrm{~B}$ \\
\hline 3 & $\begin{array}{l}\text { Jika dalam proses pembelajaran saya menggunakan } \\
\text { media ini saya menghadapi masalah maka saya } \\
\text { beranibertanya dan mengemukakanmasalah yang } \\
\text { saya hadapi }\end{array}$ & 5 & 3 & 5 & 13 & $86,67 \%$ & $\mathrm{~B}$ \\
\hline 4 & $\begin{array}{l}\text { Penyajian materi di media mendorong saya untuk } \\
\text { berdiskusi dengan teman-teman lain }\end{array}$ & 5 & 5 & 4 & 14 & $93,33 \%$ & SB \\
\hline 5 & Materi yang disajikan sudah runtun & 5 & 4 & 4 & 13 & $86,67 \%$ & $\mathrm{~B}$ \\
\hline 6 & $\begin{array}{l}\text { Saya dapat mengikuti kegiatan belajar tahap demi } \\
\text { tahap dengan mudah }\end{array}$ & 5 & 3 & 5 & 13 & $86,67 \%$ & $\mathrm{~B}$ \\
\hline 7 & $\begin{array}{l}\text { Saya dapat dengan mudah memahami kalimat yang } \\
\text { digunakan dalam media ini }\end{array}$ & 4 & 4 & 4 & 12 & $80 \%$ & B \\
\hline \multirow[t]{2}{*}{8} & $\begin{array}{l}\text { Tidak ada kalimat yang menimbulkan makna ganda } \\
\text { dalam media ini. }\end{array}$ & 4 & 5 & 4 & 13 & $86,67 \%$ & B \\
\hline & Rata-rata & & & & 8,41 & $84,12 \%$ & SB \\
\hline
\end{tabular}

Tabel 5. Skor Penilaian Media Pembelajaran Mata Pelajaran Matematika Pada Uji Coba Perorangan Tentang Kualitas Materi Pelajaran.Tentang Aspek Manfaat.

\begin{tabular}{|c|c|c|c|c|c|c|c|}
\hline \multirow{2}{*}{ No } & \multirow{2}{*}{ Indikator Penilain } & \multicolumn{3}{|c|}{ Responden } & \multirow{2}{*}{$\begin{array}{l}\text { Jumlah } \\
\text { Skor }\end{array}$} & \multirow{2}{*}{$\begin{array}{l}\text { Penyamp } \\
\text { aian }\end{array}$} & \multirow{2}{*}{$\begin{array}{l}\text { Krite } \\
\text { ria }\end{array}$} \\
\hline & & $\mathbf{1}$ & 2 & 3 & & & \\
\hline 1 & $\begin{array}{l}\text { Saya dapat memahami materi segitiga dan } \\
\text { segiempat menggunakan media ini dengan mudah }\end{array}$ & 4 & 5 & 4 & 13 & $86,67 \%$ & $\mathrm{~B}$ \\
\hline 2 & $\begin{array}{l}\text { Saya merasa lebih mudah belajar dengan } \\
\text { menggunakan media ini }\end{array}$ & 4 & 4 & 4 & 12 & $80 \%$ & B \\
\hline 3 & Saya dapat tertarik menggunakan media ini & 5 & 5 & 5 & 15 & $100 \%$ & SB \\
\hline 4 & $\begin{array}{l}\text { Dengan menggunakan media ini saya lebih tertarik } \\
\text { dalam belajar matematika }\end{array}$ & 4 & 5 & 5 & 14 & $93,33 \%$ & SB \\
\hline 5 & $\begin{array}{l}\text { Dengan adanya ilustrasi di setiap awal materi } \\
\text { dapat memberikan motivasi untuk mempelajari } \\
\text { materi segitiga dan segiempat }\end{array}$ & 4 & 4 & 5 & 13 & $86,67 \%$ & B \\
\hline \multirow[t]{2}{*}{6} & Saya lebih rajin belajar menggunakan media ini & 5 & 4 & 4 & 13 & $86,67 \%$ & B \\
\hline & Rata-rata & & & & 8,88 & $88,89 \%$ & SB \\
\hline
\end{tabular}

\section{Data Hasil Uji Coba Kelompok Kecil}

Uji coba kelompok kecil dilakukan. Uji coba kelompok kecil dilakukan terhadap 9 orang siswa dengan kemampuan kurang, sedang, dan pandai. Data uji coba kelompok kecil ini dimaksudkan untuk mengetahui kembali persepsi siswa terhadap media pembelajaran yang telah dikembangkan dan yang telah direvisi dari kelemahan-kelemahan yang tampak setelah dilakukan uji coba perorangan. 
Tabel 6. Skor Penilaian Media Pembelajaran Mata Pelajaran Matematika Pada Uji Coba Perorangan Tentang Kualitas Materi Pelajaran.Tentang Aspek Tampilan.

\begin{tabular}{|c|c|c|c|c|c|c|}
\hline \multirow{2}{*}{ No } & \multirow{2}{*}{ Indikator Penilain } & \multicolumn{3}{|c|}{ Skor } & \multirow{2}{*}{$\begin{array}{l}\text { Penyamp } \\
\text { aian }\end{array}$} & \multirow{2}{*}{$\begin{array}{l}\text { Krite } \\
\text { ria }\end{array}$} \\
\hline & & $\begin{array}{lll}1 & 2 & 3 \\
\end{array}$ & 4 & 5 & & \\
\hline 1 & Teks atau tulisan dalam media mudah dibaca & & 3 & 6 & $93,33 \%$ & SB \\
\hline 2 & Gambar yang disajikan jelas atau tidak & & 2 & 7 & $95,56 \%$ & SB \\
\hline 3 & $\begin{array}{l}\text { Gambar yang disajikansudah sesuai (tidak terlalu banyak } \\
\text { dan sedikit) }\end{array}$ & & 1 & 8 & $97,78 \%$ & SB \\
\hline 4 & $\begin{array}{l}\text { Adanya keterangan pada setiap gambar yang disajikan di } \\
\text { video }\end{array}$ & & 3 & 6 & $93,33 \%$ & SB \\
\hline 5 & Gambar yang disajikan menarik & & & 9 & $100 \% \%$ & SB \\
\hline 6 & Gambar yang disajikan sesuai dengan materi & & & 9 & $100 \%$ & SB \\
\hline & Rata-rata & & & & $96,66 \%$ & SB \\
\hline
\end{tabular}

Penilaian pada aspek kualitas materi secara keseluruhan dalam kriteria "Sangat pembelajaran untuk uji coba kelompok kecil Baik" yang tampak di Tabel 8 menunjukkan bahwa

Tabel 8. Skor Penilaian Media Pembelajaran Mata Pelajaran Matematika Pada Uji Coba Perorangan Tentang Kualitas Materi Pelajaran.Tentang Aspek Penyajian Materi.

\begin{tabular}{|c|c|c|c|c|c|c|}
\hline \multirow{2}{*}{ No } & \multirow{2}{*}{ Indikator Penilain } & \multicolumn{3}{|l|}{ Skor } & \multirow{2}{*}{$\begin{array}{c}\text { Penya } \\
\text { mpaian }\end{array}$} & \multirow{2}{*}{$\begin{array}{l}\text { Krite- } \\
\text { ria }\end{array}$} \\
\hline & & $\begin{array}{lll}1 & 2 & 3 \\
\end{array}$ & 4 & 5 & & \\
\hline 1 & $\begin{array}{l}\text { Media ini menjelaskan } \\
\text { konsep dengan menggunakan ilustrasi masalah } \\
\text { yang berkaitan dengan kehidupan sehari-hari }\end{array}$ & & 2 & 7 & $\begin{array}{l}95,56 \\
\%\end{array}$ & $\mathrm{~B}$ \\
\hline 2 & $\begin{array}{l}\text { Media menggunakan contoh-contoh yang berkaitan } \\
\text { dengan masalah kehidupan sehari-hari }\end{array}$ & & 1 & 8 & $97,78 \%$ & $\mathrm{~B}$ \\
\hline 3 & $\begin{array}{l}\text { Jika dalam proses pembelajaran saya menggunakan } \\
\text { media ini saya menghadapi masalah maka saya } \\
\text { beranibertanya dan mengemukakan masalah yang } \\
\text { saya hadapi }\end{array}$ & & 3 & 6 & $93,33 \%$ & $\mathrm{~B}$ \\
\hline 4 & $\begin{array}{l}\text { Penyajian materi di media mendorong saya untuk } \\
\text { berdiskusi dengan teman-teman lain }\end{array}$ & & 3 & 6 & $93,33 \%$ & SB \\
\hline 5 & Materi yang disajikan sudah runtun & & 1 & 8 & $97,78 \%$ & $\mathrm{~B}$ \\
\hline 6 & $\begin{array}{l}\text { Saya dapat mengikuti kegiatan belajar tahap demi } \\
\text { tahap dengan mudah }\end{array}$ & & 2 & 7 & $95,56 \%$ & $\mathrm{~B}$ \\
\hline 7 & $\begin{array}{l}\text { Saya dapat dengan mudah memahami kalimat yang } \\
\text { digunakan dalam media ini }\end{array}$ & & 2 & 7 & $95,56 \%$ & $\mathrm{~B}$ \\
\hline \multirow[t]{2}{*}{8} & $\begin{array}{l}\text { Tidak ada kalimat yang menimbulkan makna ganda } \\
\text { dalam media ini. }\end{array}$ & & 3 & 6 & $93,33 \%$ & $\mathrm{~B}$ \\
\hline & Rata-rata & & & & $95,27 \%$ & SB \\
\hline
\end{tabular}

\section{Data Hasil Uji Coba Lapangan Terbatas}

Uji coba lapangan terbatas yang terdiri dari 40 siswa. Uji coba lapangan terbatas menghasilkan data-data yang nantinya digunakan untuk mengetahui bagaimana manfaat produk bagi pemakainya. Hasil tanggapan peserta didik terhadap media pelajaran yang dikembangkan untuk uji coba lapangan terbatas keseluruhan indikator penilaian dalam kriteria "sangat baik" dengan persentase skor total Hasil uji coba lapangan terbatas dapat dilihat pada Tabel 9. 
Tabel 9. Skor Penilaian Media Pembelajaran Mata Pelajaran Matematika Pada Uji Coba Perorangan Tentang Kualitas Materi Pelajaran.Tentang Aspek Tampilan.

\begin{tabular}{|c|c|c|c|c|c|c|c|c|}
\hline \multirow{2}{*}{ No } & \multirow{2}{*}{ Indikator Penilain } & \multicolumn{5}{|c|}{ Skor } & \multirow{2}{*}{$\begin{array}{l}\text { Penyam } \\
\text { paian }\end{array}$} & \multirow{2}{*}{ Kriteria } \\
\hline & & 1 & 2 & 3 & 4 & 5 & & \\
\hline 1 & Teks atau tulisan dalam media mudah dibaca & & & & 10 & 30 & $88,24 \%$ & B \\
\hline 2 & Gambar yang disajikan jelas atau tidak & & & & & 40 & $100 \%$ & SB \\
\hline 3 & $\begin{array}{l}\text { Gambar yang disajikansudah sesuai (tidak terlalu } \\
\text { banyak dan sedikit) }\end{array}$ & & & & 10 & 30 & $88,24 \%$ & B \\
\hline 4 & $\begin{array}{l}\text { Adanya keterangan pada setiap gambar yang } \\
\text { disajikan di video }\end{array}$ & & & & 5 & 35 & $94,18 \%$ & SB \\
\hline 5 & Gambar yang disajikan menarik & & & & 5 & 35 & $94,18 \%$ & SB \\
\hline 6 & Gambar yang disajikan sesuai dengan materi & & & & 5 & 35 & $94,18 \%$ & SB \\
\hline & Rata-rata & & & & & & $93,17 \%$ & SB \\
\hline
\end{tabular}

Tabel 11.Skor Penilaian Media Pembelajaran Mata Pelajaran Matematika Pada Uji Coba Lapangan Tentang Aspek Penyajian Materi.

\begin{tabular}{|c|c|c|c|c|c|c|}
\hline \multirow{2}{*}{ No } & \multirow{2}{*}{ Indikator Penilain } & \multicolumn{3}{|l|}{ Skor } & \multirow{2}{*}{$\begin{array}{l}\text { Penyam } \\
\text { paian }\end{array}$} & \multirow{2}{*}{ Kriteria } \\
\hline & & 123 & 4 & 5 & & \\
\hline 1 & $\begin{array}{l}\text { Media ini menjelaskan konsep dengan } \\
\text { menggunakan ilustrasi masalah yang berkaitan } \\
\text { dengan kehidupan sehari-hari }\end{array}$ & & 10 & 30 & $88,24 \%$ & $\mathrm{~B}$ \\
\hline 2 & $\begin{array}{l}\text { Media menggunakan contoh-contoh yang berkaitan } \\
\text { dengan masalah kehidupan sehari-hari }\end{array}$ & & 5 & 35 & $94,18 \%$ & SB \\
\hline 3 & $\begin{array}{l}\text { Jika dalam proses pembelajaran saya menggunakan } \\
\text { media ini saya menghadapi masalah maka saya } \\
\text { beranibertanya dan mengemukakan masalah yang } \\
\text { saya hadapi }\end{array}$ & & 4 & 36 & $87,5 \%$ & $\mathrm{~B}$ \\
\hline 4 & $\begin{array}{l}\text { Penyajian materi di media mendorong saya untuk } \\
\text { berdiskusi dengan teman-teman lain }\end{array}$ & & 5 & 35 & $94,18 \%$ & SB \\
\hline 5 & Materi yang disajikan sudah runtun & & & 40 & $100 \%$ & SB \\
\hline 6 & $\begin{array}{l}\text { Saya dapat mengikuti kegiatan belajar tahap demi } \\
\text { tahap dengan mudah }\end{array}$ & & 4 & 36 & $87,5 \%$ & $\mathrm{~B}$ \\
\hline 7 & $\begin{array}{l}\text { Saya dapat dengan mudah memahami kalimat yang } \\
\text { digunakan dalam media ini }\end{array}$ & & 10 & 30 & $88,24 \%$ & B \\
\hline \multirow[t]{2}{*}{8} & $\begin{array}{l}\text { Tidak ada kalimat yang menimbulkan makna ganda } \\
\text { dalam media ini. }\end{array}$ & & 10 & 30 & $88,24 \%$ & B \\
\hline & Rata-rata & & & & $91,01 \%$ & SB \\
\hline
\end{tabular}

Uji coba lapangan pada 40 siswa ternyata secara umum siswa menyatakan bahwa media pembelajaran pada aspek penyajian materi yang dikembangkan sangat baik dengan persentase $91,01 \%$ dan tidak harus diperbaiki.

Tabel 13. Persentase Rata-rata Hasil Penilaian Ahli Materi Terhadap Media

\begin{tabular}{llcc}
\hline No & $\begin{array}{l}\text { Indikator } \\
\text { Penilaian }\end{array}$ & $\begin{array}{l}\% \text { Rata- } \\
\text { rata }\end{array}$ & Kriteria \\
\hline 1 & $\begin{array}{l}\text { Aspek kualitas } \\
\text { materi }\end{array}$ & $86,66 \%$ & $\mathrm{~B}$ \\
2 & $\begin{array}{l}\text { Aspek strategi } \\
\text { pembelajaran } \\
3\end{array}$ & $90 \%$ & $\mathrm{SB}$ \\
& $\begin{array}{l}\text { Aspek system } \\
\text { penyampaian } \\
\text { pembelajaran }\end{array}$ & $90 \%$ & $\mathrm{SB}$ \\
\hline & Rata-rata & $88,88 \%$ & $\mathrm{SB}$ \\
\hline
\end{tabular}

\section{Analisis Data Penilaian Ahli Desain}

Pembelajaran

Tabel 14. Persentase Rata-rata Hasil Penilaian Ahli Desain Pembelajaran Terhadap Media Pembelajaran Matematika

\begin{tabular}{clcc}
\hline No & Indikator Penilaian & $\begin{array}{c}\text { Persentase } \\
\text { Rata-rata }\end{array}$ & $\begin{array}{c}\text { Krit } \\
\text { eria }\end{array}$ \\
\hline 1 & $\begin{array}{l}\text { Kualitas desain } \\
\text { pembelajaran }\end{array}$ & $93,33 \%$ & $\mathrm{SB}$ \\
2 & $\begin{array}{l}\text { Kualitas desain } \\
\text { Informasi }\end{array}$ & $86,66 \%$ & $\mathrm{SB}$ \\
3 & $\begin{array}{l}\text { Kualitas desain } \\
\text { interaksi }\end{array}$ & $86,66 \%$ & $\mathrm{SB}$ \\
4 & $\begin{array}{l}\text { Kualitas desain } \\
\text { presentasi }\end{array}$ & $84,44 \%$ & $\mathrm{SB}$ \\
\hline & Rata-rata & $87,77 \%$ & $\mathrm{SB}$ \\
\hline
\end{tabular}




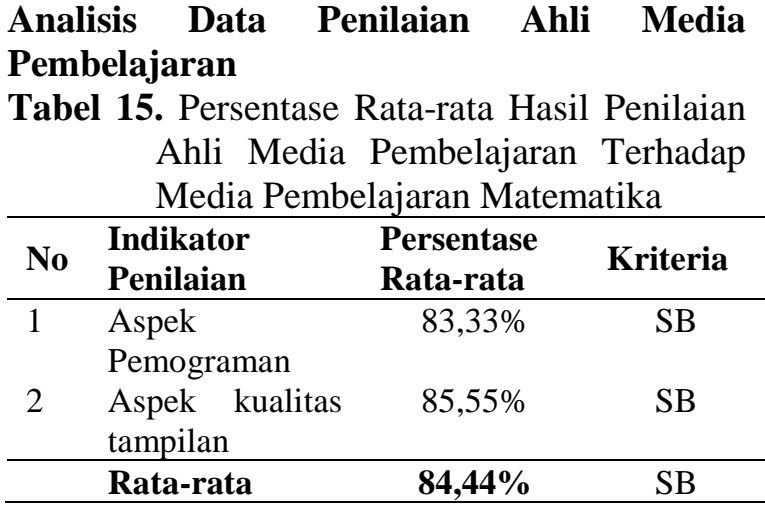

\section{Analisis Data Hasil Uji Coba Perorangan}

Hasil uji coba perorangan tentang persepsi siswa terhadap media pembelajaran yang dikembangkan menunjukkan kriteria sangat baik dengan persentase rata-rata $85,42 \%$. Pelaksanaan uji coba perorangan ini bertujuan untuk mengetahui pendapat awal siswa sebagai pengguna sebelum dilakukannya uji coba kelompok kecil. Persepsi siswa terdiri dari beberapa kategori indikator penilaian yaitu aspek kualitas materi pembelajaran, aspek kualitas tampilan dan aspek manfaat.

Tabel 16. Persentase Perolehan Skor Uji Coba Perorangan Terhadap Media Pembelajaran Matematika

\begin{tabular}{|c|c|c|c|}
\hline No & $\begin{array}{l}\text { Indikator } \\
\text { Penilaian }\end{array}$ & $\begin{array}{l}\text { Persentase } \\
\text { Rata-rata }\end{array}$ & Kriteria \\
\hline 1 & $\begin{array}{l}\text { Aspek kualitas } \\
\text { materi } \\
\text { pembelajaran }\end{array}$ & $84,12 \%$ & SB \\
\hline 2 & $\begin{array}{l}\text { Aspek kualitas } \\
\text { tampilan }\end{array}$ & $83,27 \%$ & SB \\
\hline \multirow[t]{2}{*}{3} & Aspek manfaat & $88,89 \%$ & SB \\
\hline & Rata-rata & $85,42 \%$ & SB \\
\hline
\end{tabular}

\section{Analisis Data Hasil Uji Coba Kelompok Kecil}

Tabel 17. Persentase Perolehan Skor Uji Coba Kelompok Kecil Terhadap Media Pembelajaran Matematika

\begin{tabular}{llcc}
\hline No & Indikator Penilaian & $\begin{array}{c}\text { Persentase } \\
\text { Rata-rata }\end{array}$ & $\begin{array}{c}\text { Krit } \\
\text { eria }\end{array}$ \\
\hline 1 & $\begin{array}{l}\text { Aspek kualitas materi } \\
\text { pembelajaran }\end{array}$ & $96,66 \%$ & SB \\
2 & $\begin{array}{l}\text { Aspek kualitas } \\
\text { tampilan }\end{array}$ & $83,27 \%$ & SB \\
3 & Aspek manfaat & $90 \%$ & SB \\
\hline & Rata-rata & $\mathbf{8 9 , 9 7 \%}$ & SB \\
\hline
\end{tabular}

Analisis Data Hasil Uji Coba Lapangan

Tabel 18. Persentase Perolehan Skor Uji Coba Lapangan Terbatas Terhadap Media Pembelajaran Matematika

\begin{tabular}{llrc}
\hline No & $\begin{array}{l}\text { Indikator } \\
\text { Penilaian }\end{array}$ & $\begin{array}{l}\text { Persentase } \\
\text { Rata-rata }\end{array}$ & $\begin{array}{l}\text { Kriteri } \\
\text { a }\end{array}$ \\
\hline 1 & Aspek Tampilan & $93,17 \%$ & SB \\
2 & Aspek Penyajian & $91,01 \%$ & SB \\
& Materi & & \\
\hline & Rata-rata & $\mathbf{9 2 , 0 9 \%}$ & SB \\
\hline
\end{tabular}

\section{Pengajuan Hipotesis}

Hipotesis yang diajukan pada penelitian ini adalah terdapat perbedaan yang signifikan antara hasil belajar siswa yang dibelajarkan dengan penggunaan media pembelajaran dan hasil belajar siswa yang dibelajarkan dengan menggunakan buku teks. Pengujian hipotesis yang digunakan adalah uji beda. Dari hasil perhitungan diperoleh $\mathrm{t}_{\text {hitung }}=6,557$ sedangkan $\mathrm{t}_{\text {tabel }}=2,024$. Karena $\mathrm{t}_{\text {hitung }}=6,557>\mathrm{t}_{\text {tabel }}=$ 2,024 maka disimpulkan ada perbedaan yang signifikan dalam prestasi belajar siswa yang menggunakan media pembelajaran dengan yang menggunakan buku teks.

Tabel 19. Rangkuman Perhitungan Uji Hipotesis

\begin{tabular}{|c|c|c|c|c|}
\hline \multicolumn{2}{|c|}{$\begin{array}{l}\text { Rata-rata Nilai } \\
\text { Postes }\end{array}$} & \multicolumn{2}{|c|}{$t_{\text {hitungtabel }}$} & $\begin{array}{c}\text { Kkesimpul } \\
\text { an } \\
\end{array}$ \\
\hline $\begin{array}{c}\text { Mengguna } \\
\text { kan Media } \\
\text { Pembelajar } \\
\text { an }\end{array}$ & $\begin{array}{c}\text { Menggu } \\
\text { nakan } \\
\text { Buku } \\
\text { Teks }\end{array}$ & $\begin{array}{c}6,55 \\
7\end{array}$ & $\begin{array}{c}2,02 \\
4\end{array}$ & $\begin{array}{c}\text { Ada } \\
\text { perbedaan }\end{array}$ \\
\hline 78,38 & 65,71 & & & \\
\hline
\end{tabular}

Dari hasil pengujian hipotesis diperoleh bukti empirik bahwa prestasi belajar siswa yang menggunakan media pembelajaran dalam belajarnya lebih tinggi dibandingkan dengan menggunakan buku teks dengan efektivitas penggunaan media pembelajaran $78,38 \%$.

\section{PEMBAHASAN}

Produk pengembangan media pembelajaran pada mata pelajaran Matematika merupakan materi pembelajaran Matematika yang telah dikembangkan dengan memperhatikan aspek pembelajaran dan media sebagai prinsip desain pesan pembelajaran. Penelitian pengembangan produk yang dilakukan ini diarahkan untuk menghasilkan suatu produk berupa media pembelajaran mata pelajaran Matematika yang digunakan untuk meningkatkan proses pembelajaran maupun kompetensi 
peserta didik. Karena itu dalam prosesnya penelitian ini dilakukan dengan diawali studi pendahuluan, kemudia mendesain media pembelajaran, melakukan validasi produk dan melakukan revisi dan penyempurnaan berdasarkan analisis data validasi dari ahli materi, ahli desain pembelajaran dan ahli media pembelajaran yang dilanjutkan dengan uji coba perorangan, uji coba kelompok kecil dan uji coba lapangan sehingga dihasilkan media pembelajaran yang layak digunakan sesuai dengan karakteristik bidang studi dan siswa sebagai pengguna.

Aspek revisi dan disempurnakan berdasarkan analisis data dan uji coba serta masukan dari ahli materi, ahli desain pembelajaran, ahli media dan peserta didik selaku pengguna media pembelajaran ini, berrtujuan untuk menggali beberapa aspek yang lazim dalam proses pengembangan suatu produk. Variabel-variabel media pembelajaran memiliki nilai rata-rata sangat baik. Adapun variabel media pembelajaran yang dinilai meliputi: kelayakan isi, penyajian, kebahasaan, pemograman, dan kegrafikan.

Manfaat yang diperoleh dari penggunaan media pembelajaran adalah konsep yang disajikan mudah dipelajari, dipahami, dan sistematis. Media pembelajaran memberi kesempatan pada peserta didik untuk belajar sesuai dengan kecepatan masing-masing, belajar lebih cepat dan tidak menimbulkan kebosanan masing-masing, belajar lebih cepat dan tidak menimbulkan kebosanan karena dilengkapi dengan gambar-gambar dan animasi serta soal latihan yang bervariasi. Media pembelajaran ini juga dapat digunakan sebagai alternatif media pembelajaran secara klasikal maupun individual.

\section{PENUTUP}

Hasil validasi dari ahli materi, ahli desain pembelajaran, ahli media, tanggapan uji perorangan, uji coba kelompok kecil dan uji coba lapangan terhadap media pembelajaran mata pelajaran Matematika yang dikembangkan menunjukkan bahwa seluruh aspek penilaian media pembelajaran mata pelajaran yang dikembangkan dengan menggunakan program Macromedia Flash 8.0 secara keseluruhan termasuk dalam kategori "Sangat Baik"

Pelaksanaan pembelajaran lebih efektif dengan menggunakan media pembelajaran macromedia flash pada mata pelajaran Matematika.

\section{DAFTAR PUSTAKA}

Azhar Arsyad. 2004. Media Pembelajaran. Jakarta: PT. Raja Grafindo Persada.

Andriyanto. 2010. Student Guide Series Macromedia Flash. Jakarta: PT. Elex Media Komputindo Gramedia.

Andriyanto. 2012. Student Guide Series Macromedia Flash. Jakarta: PT. Elex Media Komputindo Gramedia.

Borg, W.\& V Gall, M.D. 2005. Applying Educational Reserch (5th ed). USA

Dahar. 1996. Model - Model Mengajar. Bandung:CV.Diponogoro

Dick, W. And Carey, L. 2003. The Systematic design of Instruction. United States of America: Scoot Foresman and Company

Dimyati \& Mudjiono. 2009. Belajar dan Pembelajaran. Jakarta: Rineka Cipta.

Djamarah, Syaiful Bahri.2010.Strategi Belajar Mengajar.Jakarta: Rineka Cipta

Gagne, R.M.; Briggs,L.J \& Wager,W.W. 1992. Principles of Instruction Design. New York: Sauders College Publishing.

Hamalik, Oemar. 2006. Proses Belajar Mengajar. Jakarta: PT Bumi Aksara

Hamalik, Oemar. 2009. Dasar-Dasar Pengembangan Kurikulum. Bandung: PT. Remaja Rosdakarya

Hamzah B. Uno.2006. Perencanaan Pembelajaran: PT. Bumi Aksara

Heinich, R,et.al.1996. Instructional Media and Technology for Learning. New Jersey:Prentice Hall, Englewoodcliffs

Jayadi,L. 2008. Teknik Jitu Menguasai Macromedia Flash 8.0. Jakarta: Elexmedia Komputindo

Kemp. 1994. Design Effective Instruction. New York: Macmillan Collage Publishing Company.

Nana Sudjana \& Ahmad Rivai. 2001. Media Pengajaran. Bandung : Sinar Baru Algesindo.

Madcom.K. 2004. Cara Ampuh Menguasai Macromedia Flash 8.O.Jakarta: PT. Elex Media Komputindo

Miarso, Yusuf Hadi. 2004. Menyemai Benih Teknologi Pendidikan. Jakarta: Pustekom

Oemar Hamalik. 2008. Perencanaan Pengajaran Berdasarkan Pendekatan Sistem. Jakarta: Bumi Aksara.

Dewi Salma Prawiradilaga. 2009. Prinsip Desain Pembelajaran. Jakarta : Prenada Media Group. E. Mulyasa. 2008. 
Purwanto. 2006. Teknik Mengajar Secara Sistematis.Jakarta: Sinar Baru

Riyanto, Yatim. 2010. Paradigma Baru Pembelajaran. Jakarta: Prenada Media Group

Saiful, Sagala. 2007. Konsep dan Makna Pembelajaran. Bandung: Alfabeta

Sanjaya, W. 2008. Strategi Pembelajaran Berorientasi Standard ProsesPendidikan.Jakarta Kencana

Sardiman. 2007. Interaksi dan Motivasi Belajar Mengajar. Jakarta: Raja Grafindo Persada.

Slameto. 2005. Belajar dan Faktor - Faktor yang Mempengaruhinya. Jakarta: Rineka Cipta

Sukmadinata, Nana. 2002. Pengembangan Kurikulum: Teori dan Praktek. Bandung: PT Remaja Rosdakarya
Sutikno Sobry. 2000. Belajar dan Pembelajaran. Bandung: Prospect

Suyitno. 2008. Alternatif Pengajaran Media Komputer. UPI BANDUNG

Syaiful Bahri Djamarah. 2003. Rahasia Sukses Belajar. Jakarta : Rineka Cipta.

Uno, Hamzah B., Abdul Karim Rauf, dan Najamuddin Petta Solong. 2008. Pengantar Teori Belajar dan Pembelajaran. (Cet. II). Gorontalo: Nurul Jannah.

Yusufhadi Miarso. 2007. Menyemai Benih Teknologi Pendidikan. Jakarta: Prenada Media.

Wena, M. 2009. Strategi Pembelajaran Inovatif Kotemporee, Suatu Tinjauan Konseptual Operational. Jakarta: Bumi Aksara 